\title{
Target financial forecasting as an instrument of overcome financial difficulties in present-day global economic environment
}

\author{
Sergey Krylov ${ }^{1, *}$ \\ ${ }^{1}$ Ural Federal University, Academic Department of Accounting, Analysis and Audit, Mira 19, 620002 \\ Ekaterinburg, Russian Federation
}

\begin{abstract}
Research background: In the present-day global economic environment overcoming financial difficulties and enhance of financial position is an important goal of the anti-crisis financial management of almost any company. This goal is certain to be reached by using target financial forecasting at the company level.

Purpose of the article: The paper considers conceptual aspects of the target financial forecasting at the company level, as a new instrument of anticrisis financial management for a company to overcome its financial difficulties and enhance its financial position within a time-period of practically any length.

Methods: The methodology of the research, the results being presented in the paper, is based on the concept of the financial ratio analysis, the concept of the company cash flows, and the concept of the balanced scorecard (in terms of its financial score).

Findings \& Value added: It is depicted that the procedure of the target financial forecasting comprises an appropriate information-accounting support, a target financial forecasting of the company financial position, a target forecasting of the company's cash flows, a development of the specific events (managements' decisions) aimed at overcoming the company's financial difficulties and enhancing its financial position. The author has stated that in the present-day environment the target financial forecasting is an effective instrument of the financial forecasting that enables to set up the base for overcoming the company's financial difficulties and strengthening its financial position.
\end{abstract}

Keywords: target forecasting; financial ratios; cash flows; financial difficulties; company

JEL Classification: G39; M41; G32; G34; C02

*Corresponding author: zali6770@yandex.ru 


\section{Introduction}

The anticrisis financial management is assumed as a complex of measures based on the appropriate cash flows and aimed at the diagnostics of the company' financial difficulties and strengthening its unhealthy financial position. Each cash flows improving the company's financial position entails one or a few specific management's decisions.

In the present-day global economic environment the company faces with financial difficulties due to:

1. Insufficient attention to the market demand (for the products choice, quality, price, etc.).

2. Unsatisfactory financial company management (risks management failure, excessive financial obligations, etc.).

The first reason is considered as some kind of the unhealthy company business while the second one is taken as the unduly company financial management.

In order to manage effectively the company's cash flows with a view to overcome its financial difficulties and improve its financial position indicators and the financial ratios as well, a target financial planning and, as a consequence, target financial forecasting are employed as the forecasting having been evaluated and accepted can be taken as the major assumption in planning.

In this connection, the research of theoretical, methodical and practical aspects of the target company financial performance forecasting with the financial ratio values comprising synthesized information of the company financial position is of special importance.

Meanwhile, the present-day financial management theory and practice have developed a number of company financial performance forecast techniques; some of them basing on the financial ratios. However, the techniques described are labor-cosuming, dependent on the sales forecast and insufficiently accurate. In addition, the applications of the financial forecast technique proposed are primarily designed to be applied within the healthy company performance conditions experiencing neither financial difficulties nor the need to develop any anticrisis events.

Generally speaking, the author considers critical to develop a new method that enables to exercise the target financial forecasting within anticrisis company financial management with the key financial ratios bearing no drawbacks mentioned, i.e. sufficiently accurate, nontedious and applicable for any type of entity. In addition, to improve both the target financial forecasting efficiency and to form its information-analytical support the procedures are worth incorporating.

\section{Present-day state of the problem}

In the present-day environment the financial forecasting at the level of the company, i.e., at the micro level, presumes an application of the well-known techniques described in the relevant references on the financial accounting analysis, financial analysis, and financial management (Block, 1999; Brealey, Mayers \& Allien, 2017; Brigham \& Houston, 2015; Helfert, 2001; Higgins, 1975; McLaney, 1992; Lee,2020; Penman, 2010; Subramanyam \& Venkatachalam, 2007; Van Horne,1989, et al.) such as budgeting, percentage of revenues technique, and so-called economic-mathematical technique incorporating mathematical processing methods of time, space and time-spatial aggregate. The budgeting, percentage of revenues technique are utilized as short-term financial forecasting instruments, the economic-mathematical technique is treated as the instrument for the middle-term and longterm financial forecasting.

Consider briefly the financial forecasting technique at the micro level mentioned. 
The budgeting as the instrument of the financial forecasting presumes a calculation of a few options of the overall company budget for the period to come and a selection, by the comparative analysis, of the most optimum one for further implementation as the financial target.

As a rule, the total (main) budget of the company comprises two basic elements: target budget and financial budget. The target budget is composed of the sales forecast (sales target), the production target with the cost estimates and the income statement forecast. The financial budget consists of the cash flow budget, capital investments budget and the leading balance sheet.

The budgeting is the most accurate and detailed technique of the financial forecasting of the company performance. However, the technique is labor-consuming and is generally employed by large and middle-sized companies operating computerized financial forecasting.

Percentage of revenues technique, simple and succinct, entails the advanced assessment of coming costs, assets and liabilities in the form of the percentage of revenues for the timeperiod to come. Later the obtained data, expressed in percent, are utilized to develop the Balance Sheet forecast.

The main advantage of the percentage of revenues technique is that it is simpler and less expensive when applied. Overall, it is less accurate than the previous one; meanwhile, it enables to obtain sufficiently reliable results to be applicable mostly for small and middlesize business.

The economic-mathematical technique of the financial forecasting is based on the application of the mathematical methods to process time, space and time-spatial aggregates. The techniques are fundamental in terms of the formalized forecasting that enables to vary the complexity of the algorithms applied. A selection of the technique depends on the variety of factors, the initial data being available.

All the ingredients of the economic-mathematical technique of the financial forecasting to be executed imply an application of the complex mathematical models and powerful software for processing. It is the mainframe computer that is to be used for the purpose. In addition, a lot of statistics is needed for the case.

Having completed the brief overview of the present-day methodical instruments for the financial forecasting at the micro level we consider the methodology of the present research.

\section{Methodology of research}

The methodology of the research, the results being presented in the paper, is based on the three concepts.

1. The concept of the financial ratios analysis. At present the financial ratios analysis is considered as one of the basic instruments of the financial position and financial analysis.

Each financial ratio is a relative indicator featuring an aspect of the financial position and estimated as a ratio of one accounting indicator to another one or a relationship of two qualitative financial characteristics.

There are more than a hundred financial ratios. Many of them complement, adjust or correlate each other although they bear different names but the same accounting technique and vice versa, the same names but different accounting technique. There exist a group of the, so called, key financial ratios utilized to develop normal (recommended, standard) values facilitating qualitative evaluation of the company financial position (Krylov, 2012).

A qualified and experienced financial analyst is able to perceive a more complete understanding of the company financial position by the financial ratios analysis and interpretation rather than analyzing the characteristics in question separately (Van Horne, 1989). 
2. The concept of the company cash (fund) flows. The cash flows, sometimes called fund flows (Helfert, 2001) reflect the flow of the company assets, liabilities and Owners' equity within a certain time-period. They are treated as some kind of a link between the company financial position at the period beginning and end, defining the transformation courses from one financial position to the other and attracting the researchers' interest.

According to the author of the present article, the fund flows, i.e., the company financial resources flows in a wider sense, presume cash flows, other assets flows (expressed in value), flows of sources of funding (liabilities), financial results (earnings, expenses, taxes). To put it differently, the concept of the "fund flow" has got a much broader meaning than the concept of the "cash flow". The integrity of the company fund flow reflects the company operations turnover expressed in value. However, it should be noted, that a number of researchers, e.g., (Van Horne, 1989; Subramanyam \& Venkatachalam, 2007) identify fund flows as cash flows.

The servicing cycle of the current assets forms a foundation of the procedure. The cycle of the financial resources flows of any company can be generalized by the model of its fund (cash) flows presented in Fig. 1, frequently found in some form in the relevant references on the cash flow statement analysis, financial analysis and financial management, e.g., (Van Horne, 1989; Brigham \& Houston, 2015; McLaney, 1992; Higgins, 1975).

3. The concept of the balanced scorecard (in terms of its financial score). The balanced scorecard (BSC) as an efficient analytical instrument applied in the field of strategic management is understood as an aggregate of parameters featuring an overall company performance in the present-day market economy. The concept was developed by American scientists Robert Kaplan and David Norton at the beginning of the 90s of the XX century (Kaplan \& Norton, 1992), evolving both in their works (Kaplan, 2008), (Kaplan \& Norton, 1996, 2008, 2010), (Kaplan, Norton \& Rugelsjoen, 2010), and other researchers (Brown, 2007; Friedag \& Schmidt, 2002; Maisel, 1992; Niven, 2014; Olve, Roy \& Wetter, 2000; Rampersad, 2008), and was multiply tested.

The main goal of the balanced scorecard is to transform a company strategy into specific tangible objectives, scores and end up with events.

The BSC scores being relatively few (about 25 scores in average), they are selected (developed) depending on the outlook and strategic goals of any particular company and have individual features, so as the company managers and employees focus on the factors resulting in the outstanding achievements for the company competitiveness.

The balanced scorecard encompasses four basic interrelated scores: finance, a customer, internal business processes ones as well as training and personnel development score considered through the prism of key problems, strategic goals, scores and their target values and strategic events as well.

The developed financial balanced scorecard score which strategic goals being basic to develop the strategic goals and the rest of the BSC score is presented as a table (Table 1).

Table 1. Financial balanced scorecard score.

\begin{tabular}{|c|c|c|c|c|}
\hline $\begin{array}{c}\text { Key problem of the } \\
\text { financial balanced } \\
\text { scorecard score }\end{array}$ & $\begin{array}{c}\text { Strategic } \\
\text { financial target }\end{array}$ & $\begin{array}{c}\text { Financial } \\
\text { score }\end{array}$ & Target value & $\begin{array}{c}\text { Strategic } \\
\text { financial event }\end{array}$ \\
\hline \multirow{2}{*}{\begin{tabular}{c} 
Which targets do they \\
have to set proceeding \\
from the shareowners' \\
and shareholders' \\
\cline { 2 - 5 } financial \\
expectations?
\end{tabular}} & & & & \\
\cline { 2 - 5 } & & & & \\
\cline { 2 - 5 } & & & & \\
\hline
\end{tabular}

Source: Compiled by the author of the paper 


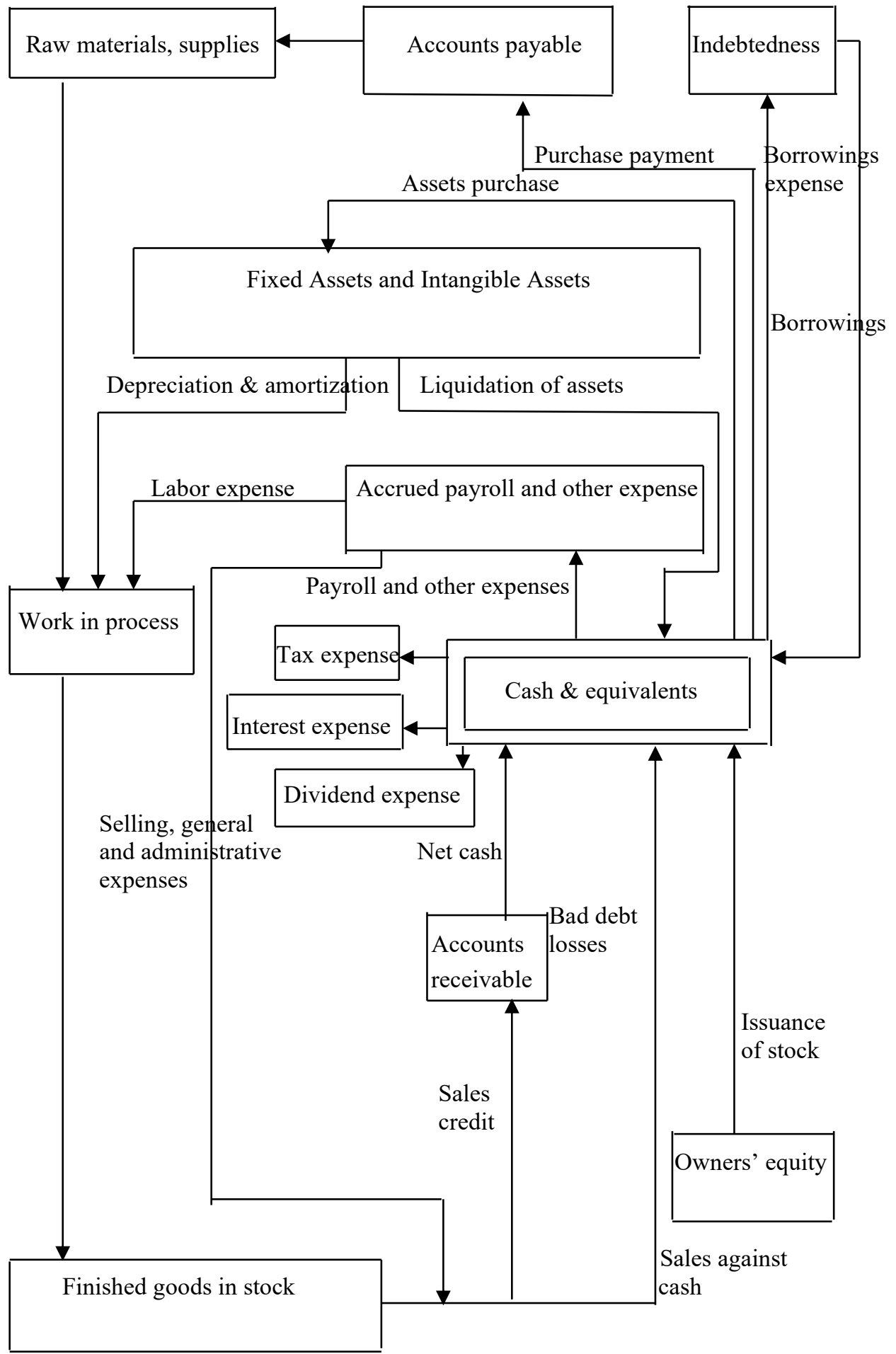

Figure 1. Model of company cash (fund) flows

Source: Compiled by the author of the paper 
The scores of the balanced scorecard system, as a whole, and its financial score are special for any particular company and are subject to its financial strategy. It has been presented in the author's previous publications that the financial BSC score indicators can be utilized by any company as the information base to exercise the applied strategic financial analysis (Krylov, 2015). The latter is a part of the applied strategic analysis and consists of the indicators values comparative assessment, diagnostics and forecast (Krylov, 2013).

The concepts of the company financial ratios, cash flows, balanced scorecard (in terms of its financial score) form the methodology of the research; the results are presented in the paper. Having succinctly characterized the latter, we consider the author's theoretical, methodical, applied and practical aspects of the target financial forecasting as the basis of the anticrisis company cash flow management.

\section{Results}

Describing the conceptual basis of the target financial forecasting as the foundation of the anticrisis financial company management the author specifies eight stages in the procedure:

1. A formation of the information base.

2. A selection of the financial ratios.

3. An analysis of the company financial position and forecasting of the financial ratios values.

4. A calculation of the leading balance sheet indicators and selected financial data.

5. A calculation of the leading net cash flows by the balance sheet items.

6. A formation of the equations system of the cash flows.

7. A calculation of the leading cash inflows and outflows.

8. A development of the events (managements' decisions) aimed at the company's overcoming its financial difficulties.

Let discuss the stages.

A formation of the information base. The author has selected a Balance Sheet, Income Statement and other forms of accounting (financial) statement complemented by the Selected Financial Data from the current accounting, further named as "the Balance Sheet and Selected Financial Data" for the information base of the target financial forecasting. To form the base the Balance Sheet is to be reclassified (i.e. regrouped), the Selected Financial Data from other financial statements and current accounting are to be attached, as well as the model of the company Cash Flows (Fig. 2) is to be transformed so that they are interlinked (agreed). The new cash flows arising in the conditions of the company bringing out of the crisis financial position are entered into the model.

A selection of the financial ratio. The financial ratios are selected from the information base by the following principles:

1. Their usefulness for the overall analysis of the company financial position with a view to ensure the position forecasting efficiency and the financial resource flow.

2. Their substantiality at the minimum of the financial ratios.

3. Their drawing up into the system of equations, the balance equalities taken into account.

The author considers expedient to classify the financial ratios into four groups featuring the main aspects of the company financial position: property position, financial stability, solvency and liquidity, business activity (comprising an intensity of the resources utilization, an efficiency of activity and resources utilization, a securities market position (for public companies).

An analysis of the company financial position and forecasting the financial ratio values. The analysis of the company financial position and the forecast of the financial ratio values presume two approaches to be carried out. 
Under the first approach the calculated financial ratio values obtained on the basis of the initial information base are compared with the actual or developed standards. If the values of one, several or all financial ratios values appear to be unsatisfactory they all are to be corrected. The leading values of the financial ratios end up. In other words, the financial ratios values are immediately corrected.

Within the second approach the financial ratio values are corrected by the overall (i.e., complex) evaluation of the company financial position.

The two options are acceptable for the matter.

The first one presumes a formation of the model of the most generalized indicator of the performance efficiency evaluation (the profitability of the assets and Owners' Equity, the ratio of the economic growth stability, etc.). The indicator is treated as the outcome index of the complex evaluation of the company performance efficiency exercised on the basis of the selected financial ratios. In this case another financial ratio is to be added to the principle of the financial ratios selection having been stated above. The ratio implies a potential to utilize the selected financial ratios as the factors within the factoring model of one of the most generalized indicators of the company performance efficiency evaluation. Later the outcome indicator value is compared with the standard one and is corrected if the result is unsatisfactory. The correctness result is understood as the leading value of the outcome indicator of the complex company performance efficiency evaluation, the values of the defining factors changing accordingly. The changes present the leading values of the financial ratios.

The second approach is associated with the rating of the company financial position by means of the selected financial ratios. The rating is exercised either by the expert score analysis or by the calculation of the integral indicator. Then the outcome rating number is compared with the standard one and is corrected if the result is unsatisfactory. The correctness result presents the leading value of the outcome rating number, the values of the financial ratios changing respectively. The changes imply the leading values of the financial ratios.

A calculation of the leading balance sheet indicators and selected financial data. The leading Balance Sheet indicators and Selected Financial Data are calculated by solving the system of equations. The system of equations is composed of the financial ratio formulae and balance equalities. The initial data for the system solution are the leading target values of the financial ratios and the condition that the value of the Balance Sheet indicator or the Selected Financial Data which are either unchanged or set to be changed.

A calculation of the leading net cash (fund) flows by the Balance Sheet items. The calculation of the leading net cash (fund) flows by the Balance Sheet items is obtained by the item deduction of the initial values from the leading Balance Sheet indicators. The leading net cash (fund) flows by the Balance Sheet items and the Selected Financial Data (which are fund flows by their economic nature, e.g.: Revenues, Net Sales, Net Income, Dividends, etc.) are assumed as the initial data to forecast the cash (fund) inflows and outflows within the transformed model of the company cash (fund) flow.

A formation of the equations system of the cash (fund) flows. This stage seems to be the most essential and complicated of the eight. The transformed model of the company cash (fund) flows must take into account all the company cash (fund) inflows and outflows and interlink them by the system of the equations. That is the complexity. It is essential that neither errors nor inaccuracy is allowed while considering and interlinking the cash (fund) flows, otherwise the desired improvement of the company financial position is not attained. The stage is not only essential and complicated but labor consuming as well, as the system will contain far more equations than that for the calculation of the leading Balance Sheet indicators and Selected Financial Data. Obviously, a number of the unknowns will noticeably exceed a number of the equations so the introduction of the initial conditions is required. The 
forecast values of the cash (fund) flows are assumed as the said condition. Certain assumptions may be introduced to simplify the system of the equations. The issue of the specific simplifying equations and initial conditions is to be settled separately in any specific case.

A calculation of the leading cash (fund) inflows and outflows. The leading cash (fund) inflows and outflows are calculated by solving the system of the equations mentioned above on the basis of the leading net cash (fund) flows by the Balance Sheet items and the initial conditions and assumptions having been determined.

A development of the events (managements' decisions) aimed at the company's overcoming its financial difficulties. The leading values of the cash (fund) inflows and outflows and the Selected Financial Data define the methods for the company to improve its financial position and overcome its financial difficulties respectively. Basing on them the events (managements' decisions) aimed at the company's overcoming its financial difficulties and improving its financial security are developed (Table 2).

The overcome of financial difficulties (improvement of financial health) as the strategic financial target, the most essential indicators of the financial statements (Balance Sheet and Selected Financial Data and the developed events (management's decisions) are to be included into the financial score of the company balance scorecard.

Table 2. Results of the target forecasting of the company cash (fund) flows.

\begin{tabular}{|c|c|c|c|c|c|}
\hline \multirow{3}{*}{$\begin{array}{c}\text { Strategic } \\
\text { financial } \\
\text { target }\end{array}$} & \multicolumn{2}{|c|}{$\begin{array}{c}\text { Indicator of financial } \\
\text { statement }\end{array}$} & \multicolumn{2}{c|}{ Cash (fund) flow } & $\begin{array}{c}\text { Events } \\
\text { (management's } \\
\text { decisions) }\end{array}$ \\
\cline { 2 - 6 } & Item & $\begin{array}{c}\text { Amount } \\
\text { thousand dollars }\end{array}$ & Item & $\begin{array}{c}\text { Amount } \\
\text { thousand dollars }\end{array}$ & \\
\hline $\begin{array}{c}\text { Overcome of } \\
\text { financial } \\
\text { difficulties } \\
\text { (improvement } \\
\text { of financial } \\
\text { health) }\end{array}$ & & & & & \\
\cline { 2 - 6 } & & & & & \\
\cline { 2 - 6 } & & & & & \\
\cline { 2 - 6 } & & & & & \\
\cline { 2 - 6 } & & & & & \\
\hline
\end{tabular}

Source: Compiled by the author of the paper

The following methods of the target financial forecasting are considered as the main leads of its practical application:

1. Anticrisis management of bankrupt company and companies at the verge of a certain degree of bankruptcy.

2. Enhancement of company investment appeal (in terms of finance).

The methodical approach is the same for both cases differing in the values of the financial ratios and initial conditions.

\section{Discussion}

Having discussed the target financial forecasting as the basis for the anticrisis financial management in terms of its conceptual, methodical and practical aspects we compare it with such financial forecasting techniques at the level of the company, i.e., the micro level, considered in the relevant references and applied today as budgeting, percentage of revenues and economic-mathematical techniques. The first two methods are applied as an instrument for short-term financial forecasting and the third one - for long-term financial forecasting.

It should be noted that all financial forecasting techniques considered (budgeting, percentage of revenues technique, economic-mathematical technique) are primarily designed 
to be applied within the healthy company performance conditions experiencing neither financial difficulties nor the need to develop any anticrisis events. For the company to find the way out of the unhealthy financial position the techniques are not sufficiently effective because the financial forecasting for the short term is based on the sales forecast (revenues). Whilst the values of the leading financial ratios characterizing the desired financial position to be attained are required in order to correct the company financial position. The values can be obtained by application of the budgeting and percentage of revenues techniques. However, the latter entails a time consuming method of selection resulting in larger number of calculation variants until the financial ratios values characterizing the desired financial position is reached. In this case the financial forecasting sequence is changed: first, forecast is financial statements data specifying the company financial position, second, forecast are its cash flows. The proposed approach simplifies the forecasting issue, extends its capacity and cuts the time taken.

The economic-mathematical technique as an instrument for middle-term and long-term financial forecasting is unlikely to be applied in unfavorable performance environment due to its features mentioned above; and therefore cannot be considered as a means of the target financial forecasting to improve the company financial.

Hence, compared with the current methods of the budgeting, percentage of revenues and economic-mathematical technique the target financial forecasting is the most effective instrument of the financial forecasting that enables to design the basis for the company to overcome its financial difficulties.

\section{Conclusions}

Summarizing the conceptual aspects of the target financial forecasting at the micro level, i.e., at the level of a company, the author of the paper has drawn the following conclusions:

The target financial forecasting is a new instrument of the anticrisis financial management aimed at overcoming the company's financial difficulties and enhancing its financial position within a time-period of practically any length. The methodology is based on the concept of the financial ratio analysis, the concept of the company cash (fund) flows, and the concept of the Balanced Scorecard (in terms of its financial score). The procedure of the target financial forecasting comprises an appropriate informational-accounting support, the target financial forecasting of the company financial position, the target forecasting of the company's cash flows, a development of the specific events (management's decisions) aimed at overcoming the company's financial difficulties and enhancing its financial position.

In the present-day environment the target financial forecasting can be an effective instrument of the financial forecasting that enables to set up the base for the company to overcome its financial difficulties and enhance its financial position.

The major fields of the target financial forecasting application are an anticrisis bankrupt company management, a management of the company at the verge of bankruptcy, as well as the company's investment appeal enhancement (in terms of its financial aspect).

\section{References}

1. Block, S. B. (1999). A study of financial analysts. Financial Analysts Journal, 55(4), 8692.

2. Brealey, R. A., Mayers, S. C., \& Allien, F. (2017). Principles of corporate finance. New York: McGraw-Hill Education.

3. Brigham, E. F., \& Houston, J. F. (2015). Fundamentals of financial management: Concise. Boston: Cengage Learning. 
4. Brown, M. G. (2007). Beyond the balanced scorecard. Improving business intelligence with analytics. New York: Productivity Press.

5. Friedag, H. R., \& Schmidt, W. (2002). Balanced scorecard: Mehr als ein kennzahlensystem. Berlin: Haufe Mediengruppe.

6. Helfert, E.A. (2001). Financial analysis: Tools and techniques. A guide for managers. New York: McGraw-Hill.

7. Higgins, R.C. (1975). Corporate bankruptcy and conglomerate merger. The Journal of Finance, 30(1), 93-113.

8. Kaplan, R. S. (2008). Conceptual foundations of the balanced scorecard. Handbook of Management Accounting Research, 3(1), 1253-1269.

9. Kaplan, R. S., \& Norton, D. P. (1992). The balanced scorecard: Measures that drive performance. Harvard Business Review, 70(1), 71-79.

10. Kaplan, R. S., \& Norton, D.P. (1996). The balanced scorecard: Translating strategy into action. Boston: Harvard Business School Press.

11. Kaplan, R. S. \& Norton, D. P. (2008). The execution premium: Linking strategy to operations for competitive advantage. Boston: Harvard Business School Press.

12. Kaplan, R. S., Norton D. P., \& Rugelsjoen B. (2010). Managing alliances with the balanced scorecard. Harvard Business Review, 88(1), 114-120.

13. Krylov, S. (2013). Applied strategic analysis as further balanced scorecard concept development, Proceedings of the $11^{\text {th }}$ Eurasia Business and Economics Society (EBES) conference (pp. 35-42). Ekaterinburg: Russian Acad. Sci., Inst. Econ., Ural Branch.

14. Krylov, S. (2015). Applied strategic financial analysis within strategic management of organization finance. European Journal of Business and Management, 7(15), 1-16.

15. Krylov, S. (2012). Methodological approach to company cash flows target-oriented forecasting based on financial position analysis. Economics Bulletin, 32(1), 830-836.

16. Lee, C. F. (2020). Financial econometrics, mathematics, statistics, and financial technology: an overall view. Review of Quantitative Finance and Accounting, 54(4), 1529-1578.

17. Maisel, L. S. (1992). Performance management: The balanced scorecard approach. Journal of Cost Management, 6(2), 47-52.

18. McLaney, E.J. (1992). Business finance for decision makers. London: Pitman Publishing.

19. Niven, P. R. (2014). Balanced scorecard evolution: A dynamic approach to strategy execution. Hoboken: John Willey \& Sons, Inc.

20. Olve, N.-G., Roy, J., \& Wetter, V. (2000). Performance drivers: A practical guide to using the balanced scorecard. Chichester: John Wiley \& Sons, Ltd.

21. Penman, S. (2010). Financial forecasting, risk and valuation: Accounting for the future. Abacus, 46(2), 211-228.

22. Rampersad, H.K. (2008). The way to a highly engaged and happy workforce based on the personal balanced scorecard. Total Quality Management \& Business Excellence, 19(1-2), 11-27.

23. Subramanyam, K. R., Venkatachalam, M. (2007). Earnings, cash flows, and ex post intrinsic value of equity. Accounting Review, 82(2), 457-481.

24. Van Horne, J. C. (1989). Fundamentals of financial management. Englewood Cliffs: Prentice-Hall. 